\title{
Simulating human and environmental exposure from hand-held knapsack pesticide application: Be-WetSpa-Pest, an integrative, spatially explicit modeling approach
}

Article

Accepted Version

Binder, C. R., Garcia-Santos, G., Andreoli, R., Diaz, J., Feola, G., Wittensoeldner, M. and Yang, J. (2016) Simulating human and environmental exposure from hand-held knapsack pesticide application: Be-WetSpa-Pest, an integrative, spatially explicit modeling approach. Journal of Agricultural and Food Chemistry, 64 (20). pp. 3999-4008. ISSN 0021-8561 doi: https://doi.org/10.1021/acs.jafc.5b05304 Available at https://centaur.reading.ac.uk/53664/

It is advisable to refer to the publisher's version if you intend to cite from the work. See Guidance on citing.

To link to this article DOI: http://dx.doi.org/10.1021/acs.jafc.5b05304

Publisher: American Chemical Society

All outputs in CentAUR are protected by Intellectual Property Rights law, including copyright law. Copyright and IPR is retained by the creators or other copyright holders. Terms and conditions for use of this material are defined in 
the End User Agreement.

www.reading.ac.uk/centaur

\section{CentAUR}

Central Archive at the University of Reading

Reading's research outputs online 
Article

\author{
Simulating human and environmental exposure from \\ hand-held knapsack pesticide application: Be-WetSpa- \\ Pest, an integrative, spatially explicit modeling approach \\ Claudia R. Binder, Glenda García-Santos, Romano Andreoli, \\ Jaime Diaz, Giuseppe Feola, Moritz Wittensöldner, and Jing Yang
}

J. Agric. Food Chem., Just Accepted Manuscript • DOI: 10.1021/acs.jafc.5b05304 • Publication Date (Web): 30 Jan 2016

Downloaded from http://pubs.acs.org on February 1, 2016

Just Accepted

"Just Accepted" manuscripts have been peer-reviewed and accepted for publication. They are posted online prior to technical editing, formatting for publication and author proofing. The American Chemical Society provides "Just Accepted" as a free service to the research community to expedite the dissemination of scientific material as soon as possible after acceptance. "Just Accepted" manuscripts appear in full in PDF format accompanied by an HTML abstract. "Just Accepted" manuscripts have been fully peer reviewed, but should not be considered the official version of record. They are accessible to all readers and citable by the Digital Object Identifier (DOI®). "Just Accepted" is an optional service offered to authors. Therefore, the "Just Accepted" Web site may not include all articles that will be published in the journal. After a manuscript is technically edited and formatted, it will be removed from the "Just Accepted" Web site and published as an ASAP article. Note that technical editing may introduce minor changes to the manuscript text and/or graphics which could affect content, and all legal disclaimers and ethical guidelines that apply to the journal pertain. ACS cannot be held responsible for errors or consequences arising from the use of information contained in these "Just Accepted" manuscripts. 
1 Simulating human and environmental exposure from hand-held knapsack pesticide application:

2 Be-WetSpa-Pest, an integrative, spatially explicit modeling approach

3 Claudia R. Binder ${ }^{1,2,3}$, Glenda García-Santos ${ }^{4}$, Romano Andreoli ${ }^{5}$, Jaime Diaz ${ }^{6}$, Giuseppe Feola ${ }^{7}$,

$4 \quad$ Moritz Wittensoeldner ${ }^{8}$, Jing Yang $^{9}$

$5{ }^{1}$ Department of Geography, University of Zurich, Switzerland; ${ }^{2}$ Department of Geography, LMU-

6 University of Munich, Germany; ${ }^{3}$ Institute for Environmental Engineering, ENAC, Ecole Polytechnique

7 Fédérale de Lausanne, Switzerland ${ }^{4}$ Department of Geography, Alpen-Adria-University Klagenfurt,

8 Austria; ${ }^{5}$ Agroscope, Switzerland; ${ }^{6}$ Department of Sanitary and Environmental Engineering,

9 Universidad de Boyacá, Colombia; ${ }^{7}$ Department of Geography and Environmental Science, University

10 of Reading, United Kingdom; ${ }^{8}$ Brugg 3, Trogen Switzerland; ${ }^{9}$ National Institute of Water and

11 Atmospheric Research, New Zealand

$12 *$ Both authors contributed equally to the manuscript

13 Abstract

14 This paper presents an integrative and spatially explicit modeling approach for analyzing human and 15 environmental exposure from pesticide application of smallholders in the potato producing Andean 16 region in Colombia. The modeling approach fulfills the following criteria: (i) it includes environmental 17 and human compartments; (ii) it contains a behavioral decision-making model for estimating the effect 18 of policies on pesticide flows to humans and the environment; (iii) it is spatially explicit; and (iv) it is modular and easily expandable to include additional modules, crops or technologies. The model was calibrated and validated for the Vereda La Hoya and was used to explore the effect of different policy 21 measures in the region. The model has moderate data requirements and can be adapted relatively easy to 22 other regions in developing countries with similar conditions. 
23 Keywords: integrative model, pesticide, exposure, environment, behavior, hydrology, developing

24 countries

25 Introduction

26 World-wide pesticide use in crop production has constantly been increasing since the 1950s in total 27 amount and in quantities per unit area [1,2]. Whereas in developed countries, mostly herbicides are 28 applied and the environmental impacts, e.g., fish toxicity, soil damage, are of major concern [3-6] in 29 developing countries, the bulk of pesticides used are insecticides and fungicides and human mortality 30 and morbidity due to exposure to pesticides has become a concern as it significantly affects the 31 livelihood of small farmers $[7,8]$.

32 Several tools have been developed to assess and reduce the impact of pesticides on the environment and 33 on human health [9]. Of special interest in our case is the development and use of models. A first string 34 of research develops environmental pesticide fate models. They analyze the distribution of pesticides within the environment, including plant, soil, water and in some cases through air (drift) (PEARL [10], CESMOS, BASINS (HSPF) ,[11]SWAT [12], Wet_hydro [13], etc.). A particular group of models studies explicitly the contamination of water bodies. Models in this category are for example DRIPS, EXAMS, PIRANHA a/b/c (see [14] for a review). Other models, such as empirical curves, focus on pesticide airborne or drift deposition and were developed in the temperate region for terrestrial mechanized boom sprayers [15-19]. Some of these models perform optimally after calibration for the case of hand-held knapsack sprayers, mostly used in developing countries in the tropics, recently

42 demonstrated by García-Santos et al. [20]. More sophisticate models focusing on pesticide exchange 43 with the atmosphere after applied to soils and crops are dynamic and physically based [21].The most 44 advanced model within pesticide emission models is the PestLCI model [22,23] and was developed for 45 use in agricultural life cycle assessment following mechanized spray application at local scale [24]. As 
46 these models have all been developed for special needs and conditions of use, they differ in their spatial

47 and temporal scales, time step, spatially explicitness, processes modeled, data requirements, complexity

48 and output (see [14] for a review). Furthermore, most of these models have large data requirements and

49 have never been applied in developing countries [25] and none of these models includes potential human

50 exposure of the applicators as an output.

51 Within a second string of research, tools and models have been developed to assess human exposure to

52 pesticide use. The tools range from qualitative assessment of human exposure, focusing mostly on

53 dermal exposure (e.g., DERM [26]; EASE [27]; PHED [28]; COSHH [29]; DREAM [30];

54 RISKOFDERM [31]; STOFENMANAGER [32]; see [33,34] for a review), to sophisticated quantitative

55 simulation models of pesticide emission in the air (Plume Model "Gaussian Plume" [35]; Gaussian

56 Diffusion Model (GDM) [36]; Model for Risk assessment of pesticide drift damage [37]; One-Box

57 Model [38]). These models focus specifically on human exposure and do not include environmental

58 effects. The only tools in which both the environment and human health issues are included are

59 empirical studies [39] and indicator based assessments (see [40] for a review). However, these

60 assessment methods are usually neither dynamic nor spatially explicit e.g. accumulation issues,

61 feedbacks and self-organization processes as part of the system dynamics are neglected. Furthermore,

62 another disadvantage of empirical point-based static approaches is that the evaluation of probability is

63 usually insufficiently considered [41] and key parameters might be not considered since they were

64 developed in different contexts [42].

65 A third string of models combines agricultural production models (including pesticide use and to some

66 extent environmental fate models) with economic models; an area where there has been significant

67 progress in the last years (see [43] for a review; $[44,45]$ ). The integration of models ranges from linear

68 programming models to spatially explicit multiple scales and multiple goal models [46,47]. A few 
69 models analyze the effect of environmental degradation, e.g. erosion, water contamination on farmers'

70 income and on the economic system at a regional level (e.g., ECECMOD [48]; and SAM [49]). The

71 trade-off model [50] is the only integrative model that has been applied to pesticide management of

72 potatoes in the Andes Region. It combines bio-physical models with econometric-process simulation

73 models and provides an integrated analysis of tradeoffs between economic and environmental indicators.

74 However, it has been found that farmers decision-making is often affected by parameters other than

75 economic ones such as norms and traditions [51,52] and thus behavioral models are required which, on

76 the one hand, simulate farmers' behavior and estimate the impacts of policies on pesticide use and, on

77 the other hand, can be linked to spatially explicit pesticide models estimating the impact of behavioral

78 change on human and environmental exposure. Finally, most models have high data requirements that

79 cannot be met in developing countries and thus less data demanding models are required [40].

80 This study contributes to the development of integrated models in the area of pesticide management. The

81 modeling approach, Be-WetSpa-Pest, (i) integrates a hydrological model with an extended pesticide 82 emission model considering environmental and human compartments; (ii) is coupled to a behavioral model, for estimating the effect of different policies on farmers pest control behavior, affecting pesticide distribution in the environment and onto the applicator; and (iii) has already been applied to Vereda La Hoya, Colombia, a region with low data availability.

We combine a farmer behavioural model [53], with a spatially explicit hydrology model, WetSpa [54], and a pesticide emission model, PestLCI [22]. We assess the potential human and environmental fate of pesticides due to adoption of different policies in low mechanized cultivation of potato in the Colombian Andes (a tropical region).

\section{Methods}


91 Be-WetSpa-Pest ${ }^{1}$ : Model structure. Figure 1 presents the basic model structure composed of input 92 data, core model processing and the output data. The strength of the Be-WetSpa-Pest is its modular structure, preferred over a fully integrated model approach as it facilitates the use, inclusion and adaptation of disciplinary models in the shape of modules, i.e. hydrological, fate and behavioral model, to different study areas (see also [50]), additional crops, pesticides and technologies.

$<$ Figure 1 $>$

Input data. To run the model four types of data are needed (Fig. 1 and 2 in Database box; Table 1 in 01_Supporting information): "global parameters" as parameters required for the hydrological WetSpa model and pesticide emission PestLCI model, "climate data", i.e., representative meteorological data of the catchment, "spatial metadata", i.e., spatially explicit land use, catchment, weather station and appropriation data, "pesticide data", i.e., physical and chemical properties of applied pesticides, and “external socio-economic factors", i.e., policies and crop rotation. The input data are stored in form of different GIS layers (Fig.2 File system box; Table 3 in 01_Supporting information). Ownership information was entered in GIS based on the latest Cadastral map [55]. Physical and chemical properties of applied pesticides within "pesticide data" were obtained from the PestLCI database and own empirical field experiments in similar soils [56,57].

$<$ Figure $2>$

Model processing. The core model, so-called Be-WetSpa-Pest model, is composed of a behavioral model and the WetSpa-Pest model. The "Behavioral model" predicts pesticide type (most prominent three fungicides and insecticides for the case study), amount applied, and application frequency per farmer and plot in the study area [53]: this information is used in the pesticide emission's model as total pesticide applied $\left(\mathrm{P}_{\mathrm{A}}\right.$, in equation 1$)$.

\footnotetext{
${ }^{1}$ Beta version available upon request.
} 
113 A set of influencing factors contributes in determining the probability of a farmer to adopt a fungicide 114 and insecticide application type respectively (see section 3 of 02 supporting information). Concerning 115 fungicides, the influencing factors are training delivered by pesticide producing companies, the 116 proportion of household income coming from agriculture, the sense of compliance with the prescriptive 117 social norm (i.e. other farmers recommendations), the plot area, and being member of a farmer 118 cooperative. Concerning insecticides, the influencing factors are farmer's educational level, the presence 119 of significant sources of non-agricultural income for the household, training delivered by pesticide 120 producing companies, and the plot area ([53] and 02_supporting information). The default values of 121 these factors (i.e. those used in the baseline scenario) in WetSpa-Pest correspond to those observed in 122 Vereda La Hoya [52,53].

123 The model allows for modifying the value of selected factors for each farmer, thus simulating different 124 types of interventions on pesticide use in the area. Interventions that WetSpa-Pest allows to be simulated 125 are: i) intensification of training delivered by pesticide producing companies; ii) organization of farmers 126 in a cooperative; iii) modification of household non-agricultural income sources; iv) increase/decrease of 127 farmer sense of compliance with the prescriptive social norm. It has to be noted that the policies 128 intervene on those farmers who in the baseline scenario did not already participate in a training program 129 or who were not intervened. In the behavioral model, a farmer can adopt one among three different 130 fungicide and insecticide application types that correspond to decreasing input effectiveness levels [53]. 131 The application types differ in terms of i) intensity of application (i.e. quantity of active ingredients per 132 unit of surface), ii) number of applications per agricultural cycle, and iii) class of active ingredients 133 applied, in particular with respect to the share of carbamates and pyrethoids over the total quantity of 134 fungicide and insecticide ([53] and Table 5 in 01_Supporting information). Furthermore there is the 135 option to use the option "crop rotation" based on $[58,59]$. 
136 The behavioural model is coupled to the WetSpa-Pest model and provides the interface for entering and 137 assessing policy recommendations. Application frequencies (i.e. average number of pesticide application 138 per phase of agricultural cycle) is also associated to the adoption of a fungicide and of an insecticide 139 application type, respectively. This information is used to determine application dates, which can be 140 distributed either randomly (using the math.random algorithm in which the values are chosen 141 pseudorandomly with approximately uniform distribution from the range [0.0 - 1.0]) or evenly within 142 each phase of the agricultural cycle excluding Sundays and days with rain (i.e. conditions by which 143 farmers from the study area do not apply pesticides). In addition, the first application date in a cycle 144 must be on a Tuesday (on even applications), and the application time must be between 06:00 and 17:00, 145 i.e. the time in which farmers usually work in the fields (see section 4.2 of 02 Supporting information). 146 The empirical data on pesticide use per farmer and plot proceed from the survey of $25 \%$ of the registered 147 farmers in the catchment area [52]. Therefore, an algorithm was developed to extrapolate the data from 148 these known data plots to all other agricultural plots in the study area. For details on the extrapolation 149 algorithm see section 5 of 02_Supporting information.

150 The second part of Be-WetSpa-Pest model is the WetSpa-Pest model. WetSpa-Pest is a fully distributed, 151 spatially explicit hydrology and emission pesticide model based on the WetSpa model by Liu and Smedt 152 [54] and the here modified PestLCI model [22], respectively. The model WetSpa is a GIS-based 153 distributed hydrological model for flood prediction and water balance simulation on a catchment scale 154 (for more details on the water flows on a cell basis see [54]). It was developed by the Free University of 155 Brussels and can be downloaded for free (http://www.vub.ac.be/WetSpa/). The pesticide emission model 156 PestLCI was developed in Denmark by Birkved and Hauschild [22] (updated version in [23]) to provide 157 information for the estimation of pesticide mass in the environment (air, surface water and groundwater) 158 outside of the sprayed field after aircraft, boom spray (pull tractor) or soil injection application 
159 techniques to be included in life cycle assessment. Its modular structure allows adaptation to conditions 160 for different regions and agricultural practices and techniques. A human exposure component was added 161 and drift fraction was modified for hand-held spray pest application (more details below).

162 Thus, Wetspa-Pest simulates simultaneously the dynamics and balances of water, energy and pesticide 163 on a grid (cell) basis at catchment scale. It uses as input data the type, amount, and frequency of 164 pesticides use per plot estimated based with the behavioural model [53]. As in WetSpa, WetSpa-Pest 165 simulates simultaneously water processes i.e. snow processes (freezing and melting), canopy 166 interception and potential evapotranspiration, infiltration, percolation, surface runoff generation, 167 interflow, groundwater flow and river routing, pesticide flows distribution into the compartments air, 168 water, soil and canopy, based on the modified PestLCI model and farmer's exposure fraction based on 169 own field experiments [60].

170 In our study, each cell $(30 \times 30 \mathrm{~m})$ is a unit process (technosphere in life cycle assessment studies), 171 equivalent to an agricultural field where only one crop grows, which is cultivated by one farmer with 172 spatially uniform pesticide application. The cell is vertically divided into different environmental 173 compartments i.e., air (100 m vertical), canopy, soil (soil surface, soil matrix and groundwater) (1 m soil 174 depth), as in PestLCI 2.0 [23] and additionally includes a human compartment i.e., applicator. When a 175 pesticide leaves the unit process (cell), it is considered an emission. The model takes into account 176 emissions to air, surface water and groundwater compartment like in PestLCI and additionally emissions 177 to soils outside of the cell as pesticide soil deposition from drift, as harvest (leaf uptake) and as 178 applicator (human exposure).

179 The primary pesticide distribution processes are those taking place during pesticide spray application as 180 described by the equation (1):

$\mathrm{P}_{\mathrm{A}}=\left(\mathrm{P}_{\mathrm{V}}+\mathrm{P}_{\mathrm{D}}+\mathrm{P}_{\mathrm{H}}+\mathrm{P}_{\mathrm{L}}+\mathrm{P}_{\mathrm{S}}\right) \mathrm{P}_{\mathrm{A}} / 100$ 
182 where $\mathrm{P}_{\mathrm{A}}$ is the total pesticide (active ingredient) applied (kg active ingredient/ha), $\mathrm{P}_{\mathrm{V}}$ is the pesticide 183 fraction which stays in the air of the plot $(\%), \mathrm{P}_{\mathrm{D}}$ is the pesticide drifted by wind out of the sprayed plot $184(\%), \mathrm{P}_{\mathrm{H}}$ is the pesticide that reaches the applicator (human exposure) $(\%), \mathrm{P}_{\mathrm{L}}$ is the pesticide fraction 185 deposited on the leaves (canopy) (\%) and $\mathrm{P}_{\mathrm{S}}$ is the pesticide directly reaching the soil (\%).

186 Total pesticide applied $\left(\mathrm{P}_{\mathrm{A}}\right)$ : The quantity $(\mathrm{kg} / \mathrm{ha})$ and type of active ingredients applied in a plot, and 187 the frequency of application are determined through the behavioral model (see above) developed by 188 Feola and Binder $[52,53]$.

189 Pesticide staying in the air $\left(\mathrm{P}_{\mathrm{V}}\right)$ : The value for the pesticide staying in the air depends on the type of 190 pesticide and meteorological conditions of the area. It can be entered into the model as a specific fixed 191 value. In the case of Vereda La Hoya the value of $1 \%$ was used given the measurements in the field 192 [59].

193 Pesticide drifted by wind $\left(\mathrm{P}_{\mathrm{D}}\right)$ : Hand-held spray is not a considered technique in the PestLCI or PestLCI 194 2.0. For the case of hand-held spray inpotato production, it is found that drift is higher as compared to 195 conventional boom spray with tractor [61] and therefore the here modified PestLCI includes two possibilities a fix drift fraction of 3.1\% of the applied dose as derived from García-Santos et al. [62] or calculation of drift for the first $20 \mathrm{~m}$ outside the plot in function of distance through the optimized IMAG drift calculator (v 1.1) by Holterman and Zande [16] (in PestLCI v2) after García-Santos et al. [61] (optimized parameters: $\mathrm{a}=29, \mathrm{~b}=-6.8, \mathrm{c}=18.35, \mathrm{~d}=-0.44$ ). Other equations in function of wind speed may reflect a more realistic scenario in cases where spray is conducted under wind conditions above $2 \mathrm{~m} \mathrm{~s}^{-1}$, available in García-Santos et al. [61]. This could be added into the model structure.

202 Pesticide reaching the human $\left(\mathrm{P}_{\mathrm{H}}\right)$ (not in PestLCI 2.0): $\mathrm{P}_{\mathrm{H}}$ is the fraction of the pesticide reaching the 203 farmer's clothes and is calculated by using a fixed fraction of $1 \%$ of the total pesticide derived from 204 empirical measurements [60]. The type of protection equipment used determines the final exposure of 
205 the farmers [60]. In the case we applied the model, Vereda La Hoya, farmers use gummy boots, long 206 trousers and a T-shirt covered by a "ruana" or "poncho".

207 Pesticide fraction deposited on the leaves (canopy) $\mathrm{P}_{\mathrm{L}}$ : $\mathrm{P}_{\mathrm{L}}$ in Eq. 3 depends, besides the amount of 208 pesticide drifted away and the amount landing on the applicator, on the leaf area covered and thus on the 209 growth stage of the plant,

$210 \quad \mathrm{P}_{\mathrm{L}}=\left(\mathrm{P}_{\mathrm{A}}-\mathrm{P}_{\mathrm{H}}-\mathrm{P}_{\mathrm{D}}-\mathrm{P}_{\mathrm{V}}\right) * \mathrm{v}_{\mathrm{i}}$

211 where $\mathrm{v}_{\mathrm{i}}$ is the interception fraction and represents the growth stage of the plant [63].

212 Pesticide reaching directly the soil $\left(\mathrm{P}_{\mathrm{S}}\right)$ : $\mathrm{P}_{\mathrm{S}}$ is calculated as the balance from the total amount of pesticide 213 applied and the pesticide reaching the other compartments,

$214 \quad \mathrm{P}_{\mathrm{S}}=\mathrm{P}_{\mathrm{A}}-\mathrm{P}_{\mathrm{V}}-\mathrm{P}_{\mathrm{D}}-\mathrm{P}_{\mathrm{H}}-\mathrm{P}_{\mathrm{L}}$

215 After the plot is treated, the applied pesticide is redistributed in the environment and degraded. The 216 secondary modelled processes by WetSpa-Pest after the pesticide application are infiltration into soil, 217 percolation into the groundwater (WestSpa model), and pesticide outflow of the watershed through 218 surface runoff (fraction of pesticide in the top soil liquid phase) and groundwater flow (fraction of 219 pesticide in the soil matrix liquid phase) (modified PestLCI) (see equations in 03_Supporting 220 information and coefficients in 01_Supporting information Table 2). Pesticide loss through macropore 221 flow and tillage (considered in PestLCI 2.0) is not modelled but could be incorporated into the model.

222 Output data. The output data is composed first of hydrological times series, including infiltration, 223 percolation, and evaporation, and surface runoff. The data is used to calibrate the WetSpa part of the 224 model. Second, spatially explicit pesticide concentration data onto the applicator, the crop (as harvest), 225 soil surface, soil matrix, surface runoff and groundwater is generated. Furthermore, for a specific plot, 226 the same information can be obtained as time series (Fig. 2). 
227 Case study. Be-WetSpa-Pest was implemented in a typical Andean mountainous region, the department 228 ("Departamento") of Boyacá, which contributes to ca. $26 \%$ of the national potato production and to $45 \%$ 229 at regional level despite its low productivity, and its land tenants are mainly smallholders (95\% of the 230 workforce) [20, 70]. The same area of study has been focus of recent studies on human and 231 environmental exposure from hand-held knapsack pesticide applications [20,39,40,44,45, $23252,53,60,61,62,64,69]$. The study area Vereda La Hoya has 840 ha and is located in the district La Hoya 233 of the community Tunja (Colombia) at a height of about 2800 to $3200 \mathrm{~m}$ a.s.l. It lies in the cold climate 234 thermal floor zone, with a total mean annual rainfall of $620 \pm 20 \mathrm{~mm}$. The area has prevailing south-east 235 winds with average wind speed of $1.8 \pm 1.39 \mathrm{~m} \mathrm{~s}^{-1}$ and a maximum of $7.6 \mathrm{~m} \mathrm{~s}^{-1}$ (data from this study). 236 Meteorological variables were registered every $15 \mathrm{~min}$ for 3 years, from October 2008 until October 237 2011, at $3 \mathrm{~m}$ above ground, using a low cost automatic meteorological station, Davis Vantage Pro-2, 238 installed within the watershed because no representative weather information was found in the national 239 net (IDEAM).

240 The moisture regime of the soil is ustic and soil texture according to US-Soil taxonomy is sandy loam as 241 described by García-Santos and Keller-Forrer [64] and [65]. Average pH of the soil is 5.03 \pm 0.31 . Total 242 organic carbon is $9.51 \pm 3.93 \%$ (Walcley Black method) and bulk density is $0.84 \pm 0.1 \mathrm{gr} \mathrm{cm}^{-3}[64,66]$;

243 The seasonality of water discharge is caused mainly by variations in rainfall events in May and October, 244 ranging from less than $10 \mathrm{~s}^{-1}$ in pre-event situations to above $601 \mathrm{~s}^{-1}$ during spring and autumn. 245 Discharge regularly intermits during summer. Water flow at the outlet was measured using an ultrasonic 246 Doppler sensor (Unidata STARFLOW) calibrated with a propeller. Measured water velocity was 247 multiplied by the cross section to obtain water flow $\left(1 \mathrm{~s}^{-1}\right)$. 
248 Orographic characterization of the catchment was obtained through a digital elevation model. A 249 geographic information system (GIS) was used to store digitized land use representing the watershed 250 characteristics with a grid of $100 \times 100 \mathrm{~m}$ and to convert the information to raster [55].

251 Main crop production in Vereda La Hoya is potato. The catchment lies within the second highest potato 252 producing region in Colombia, Boyacá, after Nariño [67]. In the region, mostly solanum tuberosum spp 253 is produced. The potato cycle last about 6-7 months and the average yield is low with about 7 ton/ ha 254 and cycle [53]. Farmers cultivate an average of 3 ha, which are subdivided into small plots, being to a 255 large extent distant from each other within the catchment and most located on terrains, which are not 256 appropriate for mechanization.

257 Pests are controlled through the application of insecticides and fungicides (see [53] for details) during 258 the entire cycle using hand-held sprayers, lever-operated knapsack sprayer.

259 Model calibration and validation of the hydrological module. The hydrological module was 260 calibrated following the principles of the guidelines for WetSpa calibration by Liu and Smedt [54]. First, 261 a rough calibration was made separately for the WetSpa model using the stream flow data from the 262 study area. Calibration data were from 4.9.2010 - 17.10.2010 and 28.10.2010 - 28.11.2010). These 263 periods included a precipitation event with a return period of 25 years. The gap is due to missing 264 discharge and meteorological data. Second the parameters: correction factor for evapotranspiration; 265 surface runoff exponent; threshold rainfall intensity; interflow scaling factor, and baseflow recession 266 coefficient were calibrated using the 3 months with highest rain intensity (September to November) 267 during 2010 (see also [54]). Third, the hydro-meteorological data from 29.11.2010 to 19.12.2010 was 268 used for validation of the model. To evaluate the goodness of fit of the modeled discharge during the 269 calibration and validation period, we used five statistical criteria (Table 1): the model bias [54] which is the relative mean difference between predicted and observed stream flows ( 0 represents a perfect fit); 
271 the Nash-Sutcliffe efficiency [68] cited in [54], which is used to evaluate how good the model simulates 272 the stream flow (1 indicates a perfect fit); the RMSE (root mean square error); the Pearson coefficient of 273 determination $\left(\mathrm{R}^{2}\right)$; and the standard error.

$274<$ Table 1>

275 Model validation of the pesticide module in soil. To validate the pesticide module of the WetSpa276 Pest, we modeled the concentration in soil of an active ingredient used (i) widely and (ii) in high dosage 277 in the study area. Chlorpyrifos corresponded to these characteristics and is used to protect the crop from 278 three typical pests threatening the potato crop in the study area: the soil-dwelling larvae of the Andean 279 weevil (Premnotrypes vorax), the late blight fungus (Phytophthora infestans) and the Guatemalan potato 280 moth (Tecia solanivora) [53]. The crop cycle period extended from the $20^{\text {th }}$ September until the $28^{\text {th }}$ 281 December 2009. The day and time of pesticide application, day of planting and day of harvest represent 282 real conditions as reported by the farmer. Predicted concentrations were compared to previously 283 measured concentrations in the same area [69]. The calculated concentrations in soil showed a high 284 agreement with the measured values along the different stages of growth of potatoes with an $r^{2}$ of 0.82 285 (Figure 3). The modeled values lied to a large extent within the error margin of the measured 286 concentrations.

$287<$ Figure 3>

288 Simulation scenarios. To show some of the results the model can generate, we used Be-WetSpa-Pest to 289 simulate three scenarios, i.e. a "baseline scenario", 'training by companies' and 'cooperative' 290 respectively. The latter two were developed to exemplify how the model can be used to assess the effect 291 of policies on pesticide use, and environmental and human exposure. We show the results for the use of 292 the active ingredient Mancozeb, applied six times with different time spans in between the applications, 293 from 20.07.2009 to 20.12.2009 for a specific field in the study area. 
294 All scenarios simulate fungicide and insecticide application over 4 agricultural cycles of potato 295 production (see Table 4 and Table 5 in 01_Supporting information). The first and second cycle 296 correspond to a baseline scenario, in which self-reported pesticide application rates are used [53]. The 297 initial values of parameters in the behavioral model (see section above) also correspond to observed 298 values in the study area [53]. The third and fourth agricultural cycle served to run the "training by 299 companies" and "cooperative" separately.

\section{Results and discussion: application of the Be-WetSpa-Pest model}

301 The baseline scenario. Figure 4 shows the simulation results for a specific plot of the active ingredient 302 Mancozeb funguicide (C8H12MnN4S8Zn), an ethylenebisdithiocarbamate (CAS Number:8018-01-7).

303 On the top $\mathrm{X}$-Axis and the right $\mathrm{Y}$-Axis, precipitation on the plot is depicted, on the lower X-Axis and 304 the left Y-Axis, the concentration of Mancozeb is shown. The first application (20.8.2009) took place at 305 the start of the growth phase. The amount of Mancozeb intersected by the canopy is low, a large share of 306 the Mancozeb applied (about $83 \%$ ) end in the topsoil and some infiltration occurs when there is 307 precipitation. In the larger growth stage (20.10.2009), the plant intercepts a higher percentage of the 308 pesticide leading to a lower amount reaching the topsoil (up to a share of about $48 \%$ for plant and 309 topsoil). The amount infiltrating through the topsoil to the soil is rather below $<4 \%$ and is favored is by 310 precipitation due to the wash off from canopy to topsoil and from topsoil to soil. The total amount of 311 Mancozeb accumulated in the soil is low and zero at the end of the cycle. On contrary, the concentration 312 in the topsoil decreases slowly and one could potentially encounter residues even when the next cycle 313 starts. This is not only due to the application itself, but also to the withering and degradation of the 314 vegetation stubbles after harvesting the potatoes.

$315<$ Figure 4> 
316 Figure 5 shows the spatial distribution of the pesticide concentration in the watershed for Mancozeb at 317 the end of the four simulated cycles (the same case as above). Red (Hotspots) are the plots with high 318 Mancozeb concentrations (between 4-8 kg/ha), in the green plots no pesticides were applied at all. 319 Hotspots of topsoil concentrations higher than $1 \mathrm{~kg} / \mathrm{ha}$ can only be found in a few places, however some 320 of them being close to a stream. The light green plots show the pesticide concentrations due to drift. On 321 these plots no pesticides were applied but we could simulate low concentrations of Mancozeb. The 322 contaminated plots are spatially interconnected, which is due to similar cultivation practices on 323 neighboring plots and the drift of pesticides to neighboring plots.

$324<$ Figure 5 $>$

325 Scenario analysis. In the policy scenario 'training by companies' we simulate the effect of a training 326 program held by pesticide producing companies. We considered only the farmers who had no 327 intervention in the baseline scenario. For these farmers, the introduction of the policy modifies the 328 probability of adopting one of three fungicide and insecticide application types respectively. This 329 potentially determines a variation (i.e. increase) of pesticide released into the environment. The results 330 show a marginal increase in productivity, but a significant increase in fungicide and insecticide use 331 ([53]). In the policy scenario 'cooperative' we simulate the effect of the participation of farmers in 332 producer cooperatives. The results show that this scenario significantly improves the efficacy of 333 insecticide use, that is, it reduces insecticide use rates [53].

334 Figure 6 shows the total amount of active ingredient of two fungicides and two insecticides applied in 335 the total area during one cycle (140 days) for the baseline and the two scenarios mentioned above. 336 Regarding the insecticides, Carbofuran and Permethrin, almost no differences can be found between the 337 scenarios, implying that these policy measures will not be effective in reducing exposure to pesticides in 338 the case studied. For the fungizides Mancozeb and Cymoxanil the training by pesticide producing 
339 companies significantly increases the amount of pesticides applied, whereas joining a cooperative 340 reduces the amount of fungicides applied by almost $90 \%$. This suggests that fostering cooperatives and 341 providing training and production support through the cooperatives might be a good way forward to 342 reduce the amount of fungicides applied. Even though this variable shad a strong estimated effect on 343 fungicide use it was not significant for insecticides use and was therefore not included in the equation. 344 That is, insecticide and fungicide use are determined by different sets of factors, and even when there is 345 one factor that influences both pesticide and insecticide use (e.g. the proportion of household income 346 coming from agriculture), the coefficient is not the same in both equations for the two behaviors (as 347 estimated in the statistical models [53]). This indicates the necessity for a disaggregated behavioral 348 analysis for pesticide use rather than an overall analysis looking at the amount of money spent on 349 pesticides.

$350<$ Figure 6>

351 When looking at the spatial distribution of Mancozeb (Figures $7 \mathrm{a}, \mathrm{b})$, the amount of hotspots $(>1 \mathrm{~kg} / \mathrm{ha})$ 352 increases in the case of the training scenario, whereas the areas, where pesticide amounts higher than $3531 \mathrm{~kg} / \mathrm{ha}$ can be found in the topsoil is markedly reduced in the cooperative scenario. In particular, the 354 concentration of Mancozeb in the areas close to the river is reduced. This result reflects the necessity of 355 a spatially explicit analysis (see also [50]) to provide decision support for reducing surface water 356 contamination by decreasing the pesticide concentration on plots close to surface water areas.

$357<$ Figure $7>$

358 Model use recommendations and further model developments.

359 This paper presented Be-WetSpa-Pest, a simulation model that (i) integrates a hydrological model with 360 an extended pesticide emission model considering environmental and human compartments; and (ii) is 361 coupled to a behavioral model, for estimating the effect of different policies on farmers' pest control 
362 behavior, affecting pesticide distribution in the environment and onto the applicator. The model was 363 calibrated and validated for the case of Vereda La Hoya in Colombia and provided valuable results on 364 the effect of policies on humans and environmental exposure to pesticides. We suggest the model to be 365 applicable for similar cases in developing countries, where there is low data availability. However, we 366 recommend, for the environmental part, to measure the key input variables for climate data like daily 367 precipitation and temperature from a nearby station, and to obtain a DEM of the area to be studied for 368 the spatial data.

369 It was shown that changes in farmers' behavior play a significant role for environmental and human 370 exposure and that policies affect fungicide and insecticide use in a different way. To apply Be-WetSpa371 Pest to other regions, thus, we consider that (i) the behavioral model should be validated. In a similar 372 cultural background as the case study, we expect that the influencing factors might be the same, even 373 though their impact (i.e. the estimated coefficient in the deterministic equation) might differ. In other 374 cultural contexts, it is likely that not only the influencing factors' estimated effects, but also the type of 375 influencing factors (e.g. social, economic, technical) may be different from the one validated for this 376 case study. Therefore, it is recommended that a behavioral study is carried out allowing for validating 377 the behavioral model, estimating the effect of the influencing factors, and measure the initial values of 378 quantity and type of pesticide used.

379 Furthermore, the model has some potential for expansion and further development:

380 a) Adapting to other pesticide application techniques and human behavior: The model can be easily 381 adapted to new application techniques. Thereby, the transfer-coefficients developed and applied for 382 other pesticide models can be used as input values for the coefficients to the environmental 383 compartments. For estimating the flow to the human compartment, however, experiments should be 384 performed to estimating the amount of pesticides ending on human body. Similarly, the behavioral 
model will have to be adapted as the behavioral factors that were used in this case study may not explain pesticide application decisions in cases in which the application technique is not the

b) Including pesticide uptake by plants through the root zone: As a further development of the model a

d) Including second order degradation of the active ingredient: One caveat of the model is that we considered for keeping the model easy manageable only the first order degradation of the active ingredient. We consider that given the high data uncertainties in developing countries, this is the right decision to take. If the model were adapted to regions with better data quality, it might be adequate to evaluate to which extent the inclusion of second order degradation of pesticides might make sense.

e) Include horizontal redistribution in surface water: In all compartments, except groundwater, the redistribution of pesticides, which is linked to water is vertically. This implies that horizontal 

distribution from plot to plot is not considered (and might be also very marginal). Future models could consider and complement the vertical redistribution with that horizontal redistribution.

f) Modeling farmers' behavior dynamically: In Be-WetSpa-Pest, farmer decision making is modeled through a deterministic equation. This is partly due to the fact that it was not possible to quantify the influence of farmers' perception of e.g. pesticide infestation levels, or environmental quality on pesticide application decisions [53]. In fact, little evidence exist that farmers in Vereda La Hoya changed their pesticide application decisions because of the perception of environmental impact of pesticide use. However, in Be-WetSpa-Pest there is further scope for internalizing farmers' behaviour, i.e. to model not only the impact of pesticide application on the environment, but also how farmers respond to pesticide distribution and concentration in the environment should this be relevant for the study area to which the model is applied [53].

g) Crop rotation: There is an option in the model to implement crop rotation. This allows for accounting for different amounts of pesticide applied depending on the crops produced in the region.

h) Modeling the effect of climate scenarios: Be-WetSpa-pest presents no limitation to input meteorological data (rainfall, temperature, wind speed and direction) from downscaled climate scenarios. This application might be of relevance for the risk assessment analysis of climate impacts.

Acknowledgements. The early part of this work was carried out while the authors were in the Unit for Social and Industrial Ecology, Department of Geography, University of Zurich, Switzerland. This project was funded by the Swiss National Science Foundation (SNSF) through the project number 110807. The authors thank Dr. Ronnie Jursake for valuable comments, Lisa Ketzer and Sophia Lohmayer for formatting and for editing, the students from the University of Boyacá for their support in the field work. 
431 Supporting information description.

432 Supporting information includes i) input variables and coefficients in WetSpa-Pest model, GIS layers 433 derived from the DEM (Digital Elevation Model), simulated scenarios and funguicide application types 434 (01 - Supporting information: Table 1, Table 2, Table 3, Table 4, Table 5), ii) detailed description of 435 how pesticide application data and integration of farmer decision models into the WetSpa-Pest model 436 are generated (02 - Supporting information: Generation pesticide application) and iii) detailed 437 description and equations on the secondary distribution of pesticides in the modified PestLCI (03 438 Supporting information: Redistribution and degradation processes of the pesticides).

\section{References}

441 1. Carvalho, F.P. Agriculture, pesticides, food security and food safety. Environmental Science \& 442 Policy 2006, 9, 685-692.

443 2. World Health Organization, W.H.O. Public health impact of pesticides use in agriculture. $444 \quad$ W.H.O.: Geneva, 1990.

445 3. Ecobichon, D.J. Pesticide use in developing countries. Toxicology 2001, 160, 27-33.

446 4. Younes, M.; Galal-Gorchev, H. Pesticides in drinking water - a case study. Food and Chemical $447 \quad$ Toxicology 2000, 38, 87-90.

448 5. Carlomagno, M.; Mathó, C.; Cantou, G.; Sanborn, J.R.; Last, J.A.; Hammock, B.D.; Roel, A.; 449 González, D.; González-Sapienza, G. A clomazone immunoassay to study the environmental fate 450 of the herbicide in rice (oryza sativa) agriculture. Journal of agricultural and food chemistry 2010, $58,4367-4371$. 
452 6. Zhang, R.; Cui, J.; Zhu, H.M.; Yang, H. Effect of dissolved organic matters on napropamide 453 availability and ecotoxicity in rapeseed (brassica napus). Journal of agricultural and food $454 \quad$ chemistry 2010, 58, 3232-3240.

455 7. Wilson, C.; Tisdell, C. Why farmers continue to use pesticides despite environmental, health and $456 \quad$ sustainability costs. Ecological Economics 2001, 39, 449-462.

457 8. International code of conduct on the distribution and use of pesticides: guidance on pest and 458 pesticide management policy development. Food and Agriculture Organization of the United $459 \quad$ Nations: Rome, 2010.

460 9. Rice, P.J.; Rice, P.J.; Arthur, E.L.; Barefoot, A.C. Advances in pesticide environmental fate and 461 exposure assessments. Journal of agricultural and food chemistry 2007, 55, 5367-5376.

462 10. Leistra, M.; Van der Linden, A.; Boesten, J.; Tiktak, A.; Van den Berg, F. Pearl model for 463 pesticide behaviour and emissions in soil-plant systems: Description of the processes in focus 464 465 11. Bicknell, B.R.; Imhoff, J.C.; Kittle Jr, J.L.; Jobes, T.; Donigian Jr, A.; Johanson, R. Hydrological 466 467 468 12. Neitsch, S.; Arnold, J.; Kiniry, J.; Williams, J. Soil and water assessment tool (swat) theoretical 469 documentation. Grassland soil and water research laboratory. Agricultural Research Service, simulation program-fortran: Hspf version 12 user's manual (comuputer program manual). $A Q U A$ TERRA Consultants, Mountain View, California 2001. pearl v 1.1. 1. Alterra, Green World Research Wageningen: 2001. Blackland Research Center, Texas Agricultural Experiment Station 2005.

13. Metta, J.W.P.; Bolte, J.; Vaché, K.; Jepson, P.; Jenkins, J.; Mc Donnel, J. Wethydro: A watershed-scale, fully distributed model of pesticide fate/transport. Geological Society of America Abstract with Programs 2006, 38, 40. 
474 14. Quilbé, R.; Rousseau, A.N.; Villeneuve, J.P. Gibsi: an integrated modelling software for 475 watershed management. Geophysical Research Abstracts 2006.

476 15. Ganzelmeier, H.; Rautmann, D.; Spangenberg, R.; Streloke, M. Studies on the spray drift of plant 477 478 protection products: Mitteilungen aus der biologischen bundesanstalt für land- und forstwirtschaft. 1995.

16. Holterman, H.; van De Zande, J. Imag draft report. Imag drift calculator v 1.1, user manual. 480 2003.

481 17. Holterman, H.J.; van de Zande, J.C.; Porskamp, H.A.J.; Huijsmans, J.F.M. Modelling spray drift 482 from boom sprayers. Computers and Electronics in Agriculture 1997, 19, 1-22.

483 18. Nuyttens, D.; de Schampheleire, M.; Baetens, K.; Sonck, B. The influence of operator-controlled 484 485 variables on spray drift from field crop sprayers. Transactions of the ASABE 2007, 50, 11291140.

20. García-Santos, G.; Feola, G.; Nuyttens, D.; Diaz, J. Drift from the use of hand-held knapsack pesticide sprayers in boyacá (colombian andes). Journal of agricultural and food chemistry 2015, x, xx-Xx. DOI: 10.1021/acs.jafc.5b03772

492 21. Scholtz, M.; Voldner, E.; McMillan, A.; Van Heyst, B. A pesticide emission model (pem) part i: 493 Model development. Atmospheric Environment 2002, 36, 5005-5013.

494 22. Birkved, M.; Hauschild, M.Z. Pestlci—a model for estimating field emissions of pesticides in 495 agricultural lca. Ecological Modelling 2006, 198, 433-451. 
496 23. Dijkman, T.J.; Birkved, M.; Hauschild, M.Z. Pestlci 2.0: A second generation model for 497 estimating emissions of pesticides from arable land in lca. The International Journal of Life $498 \quad$ Cycle Assessment 2012, 17, 973-986.

499 24. van Zelm, R.; Larrey-Lassalle, P.; Roux, P. Bridging the gap between life cycle inventory and 500 impact assessment for toxicological assessments of pesticides used in crop production. $501 \quad$ Chemosphere 2014, 100, 175-181.

502 25. Andreoli, R. Analysing the pesticide fate model wetspa-pest for its application in "vereda la 503 hoya, colombia": In context of the project: "Reducing human health and environmental risks $504 \quad$ from pesticide use: Integrating decisionmaking and spatial risk assessment models: The case of 505 vereda la hoya, colombia. Geographisches Institut der Universität Zürich: 2010.

506 26. Blanco, L.E.; Aragón, A.; Lundberg, I.; Wesseling, C.; Nise, G. The determinants of dermal 507 508 509

28. Dosemeci, M.; Alavanja, M.C.R.; Rowland, A.S.; Mage, D.; Hoar Zahm, S.; Rothman, N.; exposure ranking method (derm): A pesticide exposure assessment approach for developing countries. The Annals of Occupational Hygiene 2008, 52, 535-544.

27. Cherrie, J.W.; Tickner, J.; Friar, J. Evaluation of further development of the ease model 2.0. HSE Books: 2003; p viii, 127. Lubin, J.H.; Hoppin, J.A.; Sandler, D.P.; Blair, A. A quantitative approach for estimating exposure to pesticides in the agricultural health study. The Annals of Occupational Hygiene 2002, 46, 245-260.

29. Garrod, A.N.I.; Rajan-Sithamparanadarajah, R. Developing coshh essentials: Dermal exposure, 516 personal protective equipment and first aid. Annals of Occupational Hygiene 2003, 47, 577-588. 
517 30. Van-Wendel-de-Joode, B.; Brouwer, D.H.; Vermeulen, R.; van Hemmen, J.J.; Heederik, D.;

Kromhout, H. Dream: A method for semi-quantitative dermal exposure assessment. The Annals of Occupational Hygiene 2003, 47, 71-87.

31. van Hemmen, J.J.; Auffarth, J.; Evans, P.G.; Rajan-Sithamparanadarajah, B.; Marquart, H.; Oppl, R. Riskofderm: Risk assessment of occupational dermal exposure to chemicals. An introduction to a series of papers on the development of a toolkit. The Annals of Occupational Hygiene 2003, 47, 595-598.

32. Marquart, H.; Heussen, H.; Le Feber, M.; Noy, D.; Tielemans, E.; Schinkel, J.; West, J.; van der Schaaf, D. 'Stoffenmanager', a web-based control banding tool using an exposure process model. Annals of Occupational Hygiene 2008, 52, 429-441.

33. Lesmes-Fabian, C.; Teubl, S.; Binder, C.R. Evaluation of models for dermal exposure assessment in farming systems in developing countries. journal of Environmental Engineering and Ecological Science 2014, 3, 1.

34. Lesmes-Fabian, C. Correction: Dermal exposure assessment to pesticides in farming systems in developing countries: Comparison of models. Int. J. Environ. Res. Public health 2015, 12, 4670_ 4696. International journal of environmental research and public health 2015, 12, 9264.

35. Gil, Y.; Sinfort, C. Emission of pesticides to the air during sprayer application: A bibliographic review. Atmospheric Environment 2005, 39, 5183-5193.

36. Craig, I.P. The gds model - a rapid computational technique for the calculation of aircraft spray drift buffer distances. Computers and Electronics in Agriculture 2004, 43, 235-250.

37. de Schampheleire, M.; P., S.; Brusselman, E.; Sonck, S. Risk assessment of pesticide spray drift damage in belgium. Crop Protection 2007, 26, 602-611. 
539 38. Keil, C.B. A tiered approach to deterministic models for indoor air exposures. Applied 540 Occupational and Environmental Hygiene 2000, 15, 145-151.

541 39. García-Santos, G.; Scheiben, D.; Binder, C.R. The weight method: A new screening method for 542

40. Feola, G.; Rahn, E.; Binder, C.R. Suitability of pesticide risk indicators for less developed countries: A comparison. Agriculture, Ecosystems \& Environment 2011, 142, 238-245.

41. Balderacchi, M.; Trevisan, M. Comments on pesticide risk assessment by the revision of directive eu 91/414. Environmental Science and Pollution Research 2010, 17, 523-528.

42. Meli, S.M.; Renda, A.; Nicelli, M.; Capri, E. Studies on pesticide spray drift in a mediterranean citrus area. Agronomie 2003, 23, 667-672.

43. Rossing, W.A.H.; Zander, P.; Josien, E.; Groot, J.C.J.; Meyer, B.C.; Knierim, A. Integrative modelling approaches for analysis of impact of multifunctional agriculture: A review for france,

44. Feola, G.; Sattler, C.; Saysel, A.K. Simulation models in farming systems research: Potential and challenges. In Farming systems research into the 21st century: The new dynamic, Darnhofer, I.; Gibbon, D.; Dedieu, B., Eds. Springer Dordrecht, Netherlands, 2012; pp 281-306.

45. Binder, C.R.; Feola, G.; Steinberger, J.K. Considering the normative, systemic and procedural dimensions in indicator-based sustainability assessments in agriculture. Environmental Impact Assessment Review 2010, 30, 71-81.

46. Rossing, W.A.H.; Opdam, P.; van der Knaap, W.; Grashof-Bokdam, C. Landscape prototypes for multifunctional farming - seeking synergy between functional biodiversity and other green services at field, farm and landscape scales. IOBC-WPRS Bull 2003, 26, 129-134. 
562 47. Groot, J.C.J.; Rossing, W.A.H.; Jellema, A.; Stobbelaar, D.J.; Renting, H.; van Ittersum, M.K. 563 Exploring multi-scale trade-offs between nature conservation, agricultural profits and landscape 564 quality - a methodology to support discussions on land-use perspectives. Agriculture, $565 \quad$ Ecosystems \& Environment 2007, 120, 59-70.

566 48. Vatn, A.; Bakken, L.; Botterweg, P.; Romstad, E. Ececmod: An interdisciplinary modelling 567 system for analyzing nutrient and soil losses from agriculture. Ecological Economics 1999, 30, 568 189-206.

569 49. Belcher, K.W.; Boehm, M.M.; Fulton, M.E. Agroecosystem sustainability: A system simulation 570 model approach. Agricultural Systems 2004, 79, 225-241.

571 50. Stoorvogel, J.; Antle, J.M.; Crissman, C.; Bowen, W. The tradeoff analysis model: Integrated bio-physical and economic modeling of agricultural production systems. Agricultural Systems 2004, $80,43-66$.

574 51. Schoell, R.; Binder, C.R. System perspectives of experts and farmers regarding the role of 575 livelihood assets in risk perception: Results from the structured mental model approach. Risk analysis : an official publication of the Society for Risk Analysis 2009, 29, 205-222.

577 52. Feola, G.; Binder, C.R. Towards an improved understanding of farmers' behaviour: The integrative agent-centred (iac) framework. Ecological Economics 2010, 69, 2323-2333.

579 53. Feola, G.; Binder, C.R. Identifying and investigating pesticide application types to promote a 580 more sustainable pesticide use. The case of smallholders in boyacá, colombia. Crop Protection 2010, 29, 612-622.

54. Liu, Y.B.; Smedt, F.d. Wetspa extension, a gis-based hydrologic model for flooed prediction and watershed management. Documentation and user manual. 2004. 
584 55. Instituto Geográfico Agustín Codazzi, I.G.A.C. Urban and rural cadastral actualization for the 585 municipality of tunja. Departamento Nacional de Estadistica (DANE): 2005a.

586 56. Mosquera-Vivas, C.S.; García-Santos, G.; Celis-Ossa, R.E.; Hellweg, S.H.; Juraske, R.; 587 González-Murillo, C.A.; Guerrero-Dallos, J.A. Adsorption, desorption and degradation 588 behaviour of the pesticides pyrimethanil, dimethomorph and chlorpyrifos through a tropical $589 \quad$ colombian agricultural soil profile. Unpublished $a$.

590 57. Mosquera-Vivas, C.S.; Martinez-Cordon, M.J.; García-Santos, G.; Guerrero-Dallos, J.A. 591 Adsorption-desorption studies of tebuconazole in tropical colombian agricultural soils. $592 \quad$ Unpublished $b$.

593 58. Tuchschmid, M. Field survey: Roundtable with the farmers. Vereda la hoya, colombia. 2004.

594 59. Tuchschmid, M. Gis-basierende räumliche risikoabschätzung vom pestizideinsatz in der 595 landwirtschaft fallstudie: Vereda la hoya, kolumbien. Diplomarbeit, ETH (Eidgenössische 596 Technische Hochschule Zürich), Zurich, 2004.

597 60. Lesmes-Fabian, C.; García-Santos, G.; Leuenberger, F.; Nuyttens, D.; Binder, C.R. Dermal 598 exposure assessment of pesticide use: The case of sprayers in potato farms in the colombian $599 \quad$ highlands. The Science of the Total Environment 2012, 430, 202-208.

600 61. García-Santos, G.; Feola, G.; Nuyttens, D.; Diaz, J. Drift from the use of handled knapsack 601 pesticide sprayers in boyacá (colombian andes). This issue.

602 62. García-Santos, G.; Scheiben, D.; Binder, C.R. The weight method: A new screening method for 603 estimating pesticide deposition from knapsack sprayers in developing countries. Chemosphere 604 2011, $82,1571-1577$. 
605 63. Linders, J.; Mensink, H.; Stephenson, G.; Wauchope, D.; Racke, K. Foliar interception and 606 retention values after pesticide application. A proposal for standardized values for environmental risk assessment (technical report). Pure and applied chemistry 2000, 72, 2199-2218.

64. García-Santos, G.; Keller-Forrer, K. Avoidance behaviour of eisenia fetida to carbofuran, 609 chlorpyrifos, mancozeb and metamidophos in natural soils from the highlands of colombia. Chemosphere 2011, 84, 651-656.

65. Binder, C.; Patzel, N. Preserving tropical soil organic matter at watershed level. A possible contribution of urban organic wastes. Nutrient Cycling in Agroecosystems 2001, 61, 171-181.

66. Vargas, E.M. Evaluación de la lixiviación de pesticidas hacia las aguas subterráneas de la vereda de la hoya del municipio de tunja, por medio del modelo pearl 2.2.2. Trabajo de grado por universidad de boyacá, ingeniería sanitaria y ambiental. Colombia, 2005.

67. Ministerio de Agricultura y Desarrollo Rural, M. La cadena de la papa en colombia. Una mirada

68. Nash, J.; Sutcliffe, J.V. River flow forecasting through conceptual models part $\mathrm{i}-\mathrm{a}$ discussion of principles. Journal of hydrology 1970, 10, 282-290.

621 69. Juraske, R.; Mosquera Vivas, C.S.; Erazo-Velásquez, A.; García-Santos, G.; Berdugo-Moreno, M.B.; Diaz-Gomez, J.; Binder, C.R.; Hellweg, S.; Guerrero-Dallos, J.A. Pesticide uptake in potatoes: Model and field experiments. Environmental Science \& Technology 2011, 45, 651657.

625 70. Gobernación de Boyacá Direccion de Desarrollo Agropecuario. Acuerdo de competitividad de la 626 cadena agroalimentaria de la papa, para el Departamento de Boyacá. 2004, Tunja, Colombia. 
628 Table 1: Goodness of fit coefficients for the calibration and validation periods for water discharge.

629

630

631 632

\section{Figures captions}

Figure 1: Be-Westspa-Pest model structure including input, core model and output data.

Figure 2: Representation of the detailed software design of the integrative approach Be-WetSpa-Pest.

Figure 3: Comparison of measured (blue) and modeled (green) concentrations of Chlorpyrifos in soil (mg/kg soil) along the different growth stages of a potato field within the study region (La Hoya, Boyaca). Vertical bars denote standard deviation.

Figure 4: Simulation results for pesticide application of Mancozeb (six applications) on a sample field, for a total cycle of 140 days (method even). The triangles show the application dates. The dashed line and the continuous line show the soil respectively the topsoil concentration. The dotted line shows the concentration on the canopy.

Figure 5: Spatial distribution of Mancozeb concentration in the watershed. Four consecutives cycles were simulated (baseline scenario, method even). In the green marked areas no pesticides were applied during this simulation run.

Figure 6: Total amount of pesticide applied in one cycle (140 days) and the whole area. i: insecticide; f: fungicide

Figure 7: Spatial distribution of Mancozeb concentration in the watershed. Four consecutives cycles were simulated (8a: training scenario; 8b: cooperative scenario, method even). In the green marked areas no pesticides were applied during this simulation run.

\section{Tables}

\section{Table 1:}




\begin{tabular}{lcc}
\hline Coefficient & Calibration & Validation \\
\hline Model bias & -0.162 & 0.151 \\
Nash-Sutcliffe efficiency & 0.994 & 0.9966 \\
RMSE & 0.233 & 0.2375 \\
Pearson coefficient & 0.848 & 0.956 \\
Standard error & 0.012 & 0.008
\end{tabular}

651

652 
654 Figure 1:

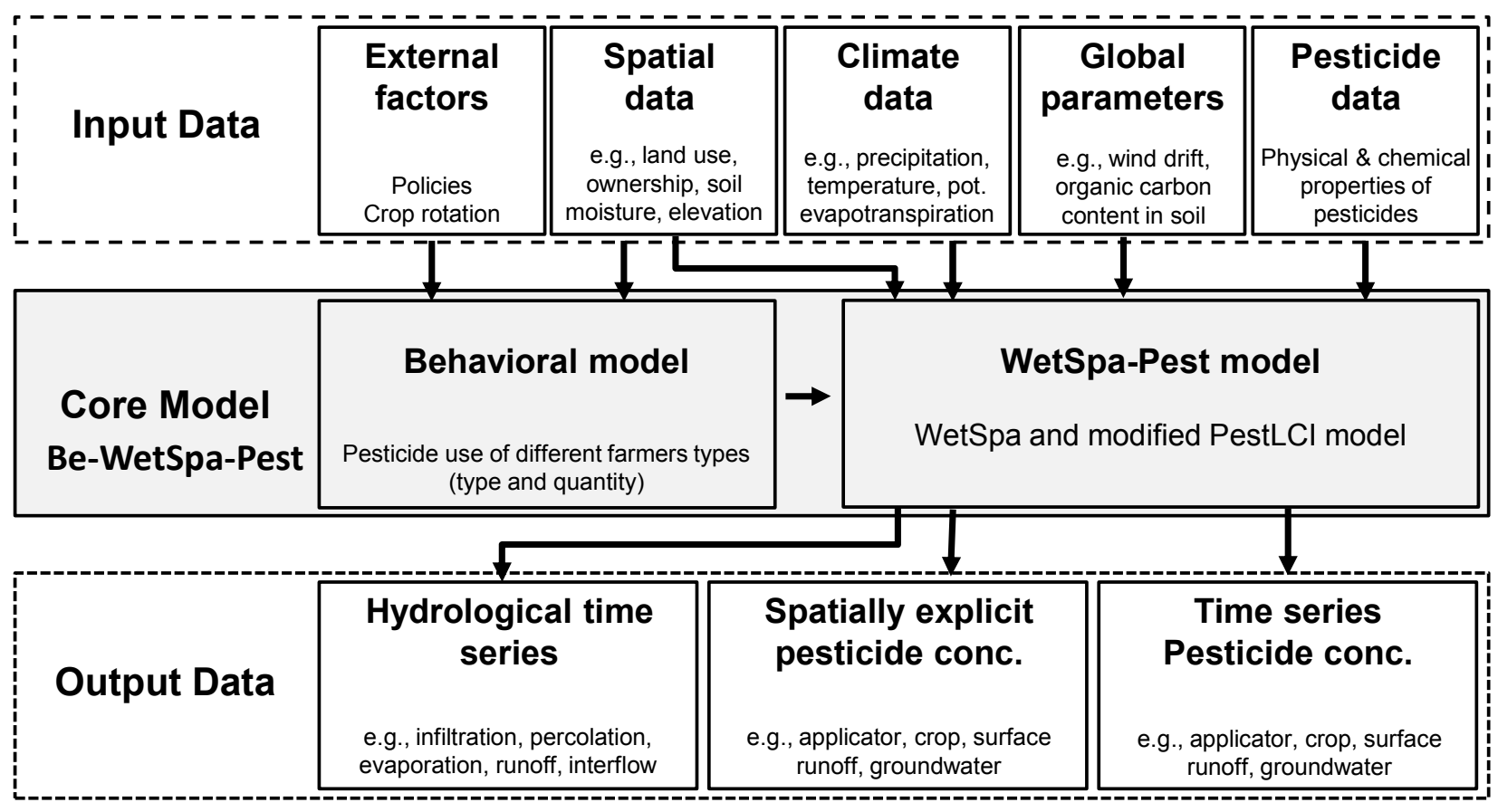




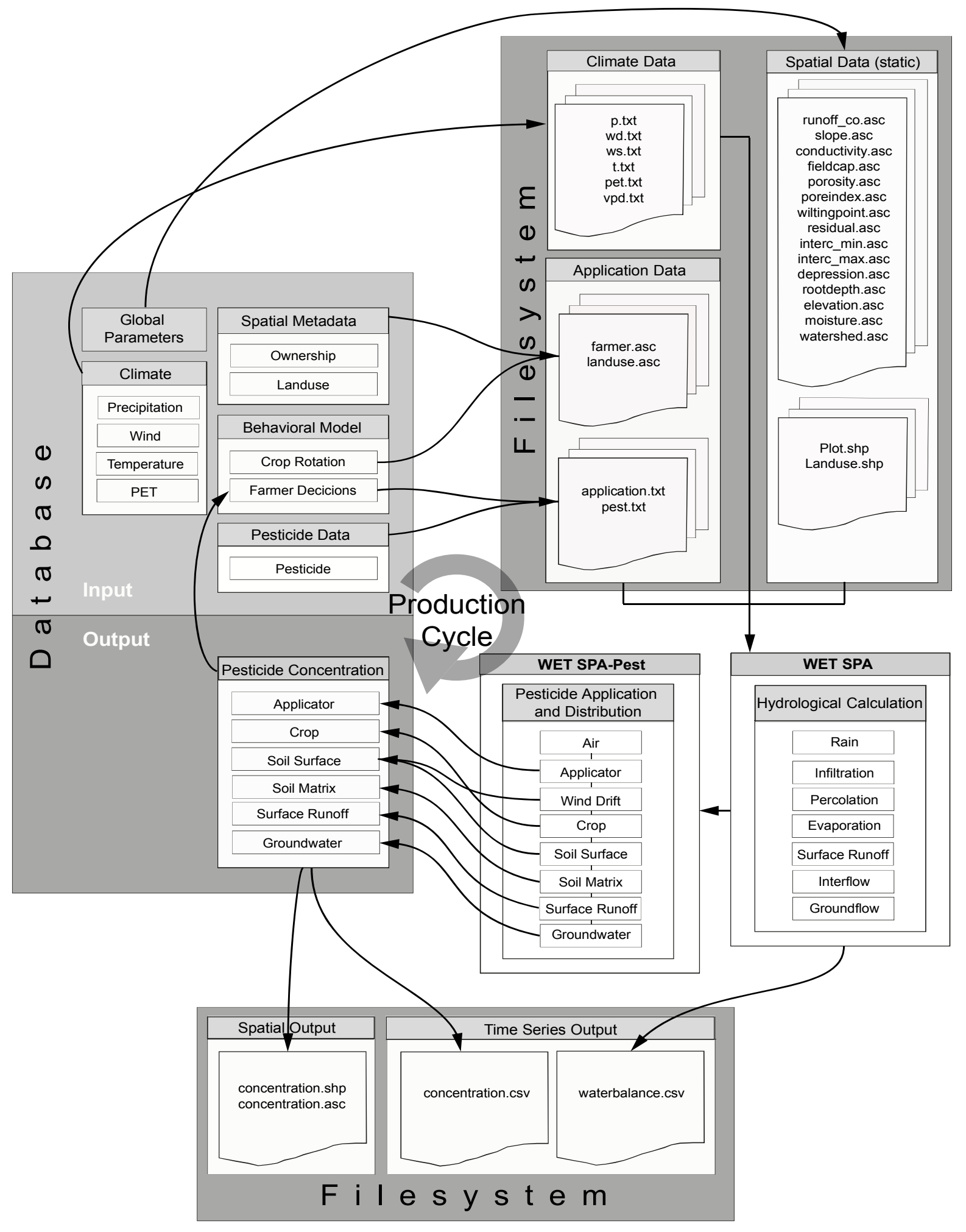


Figure 3:

671

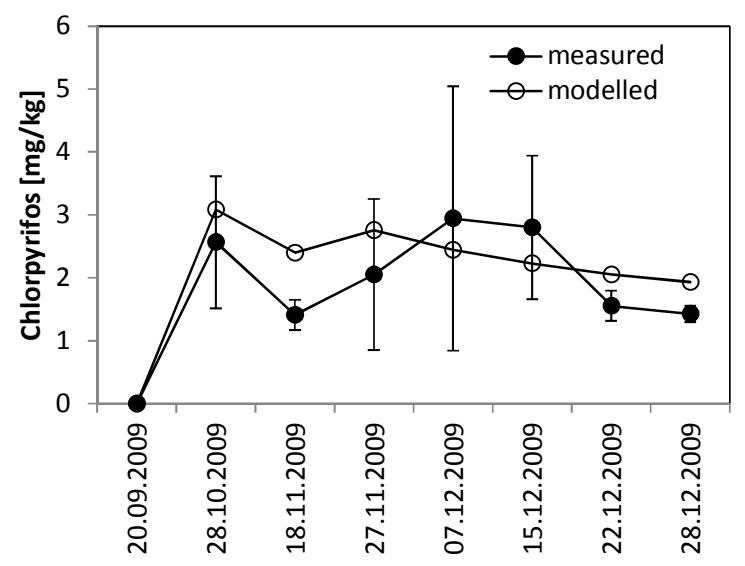

672

Figure 4:

673

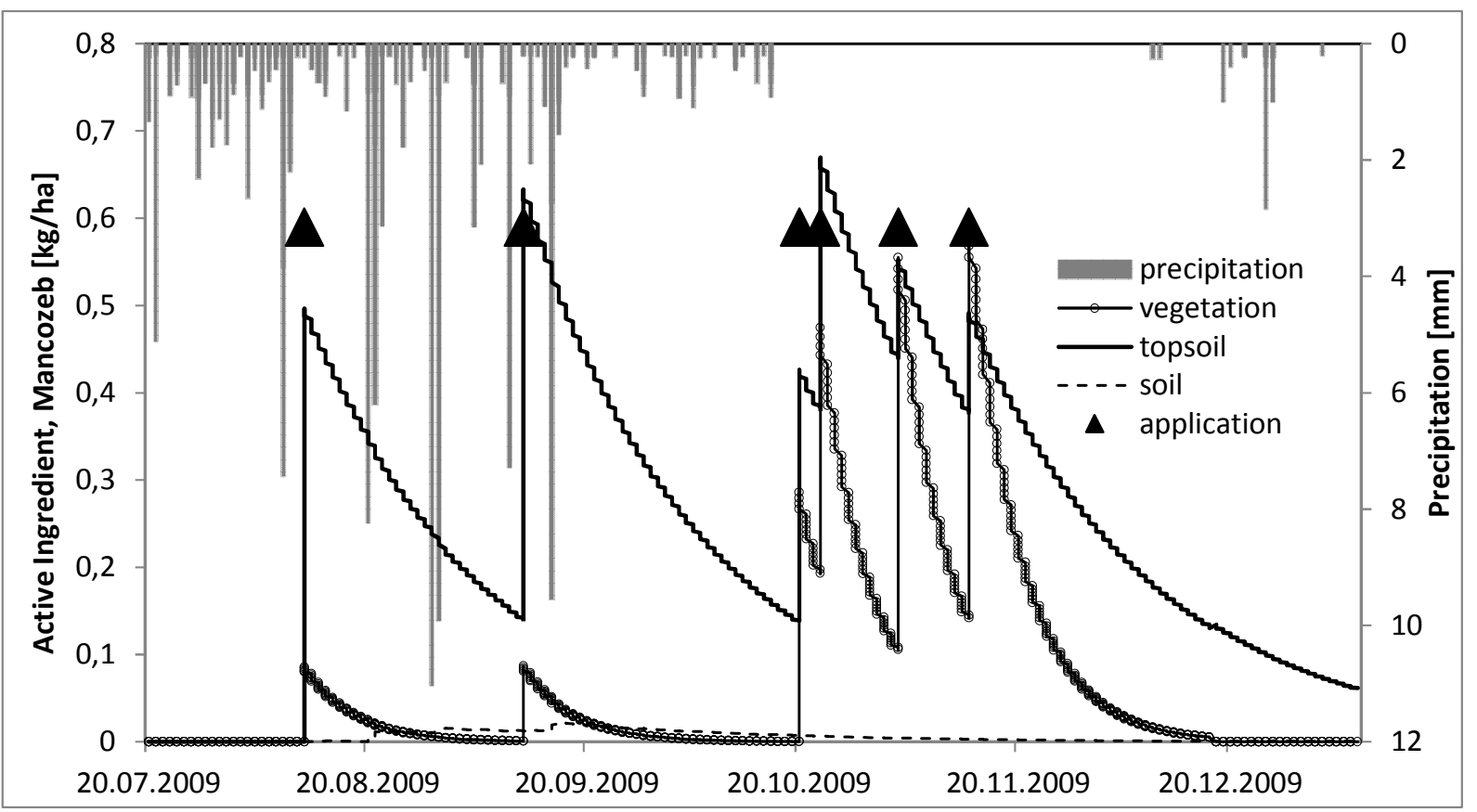

674

675

676

677

678

679 
Figure 5:

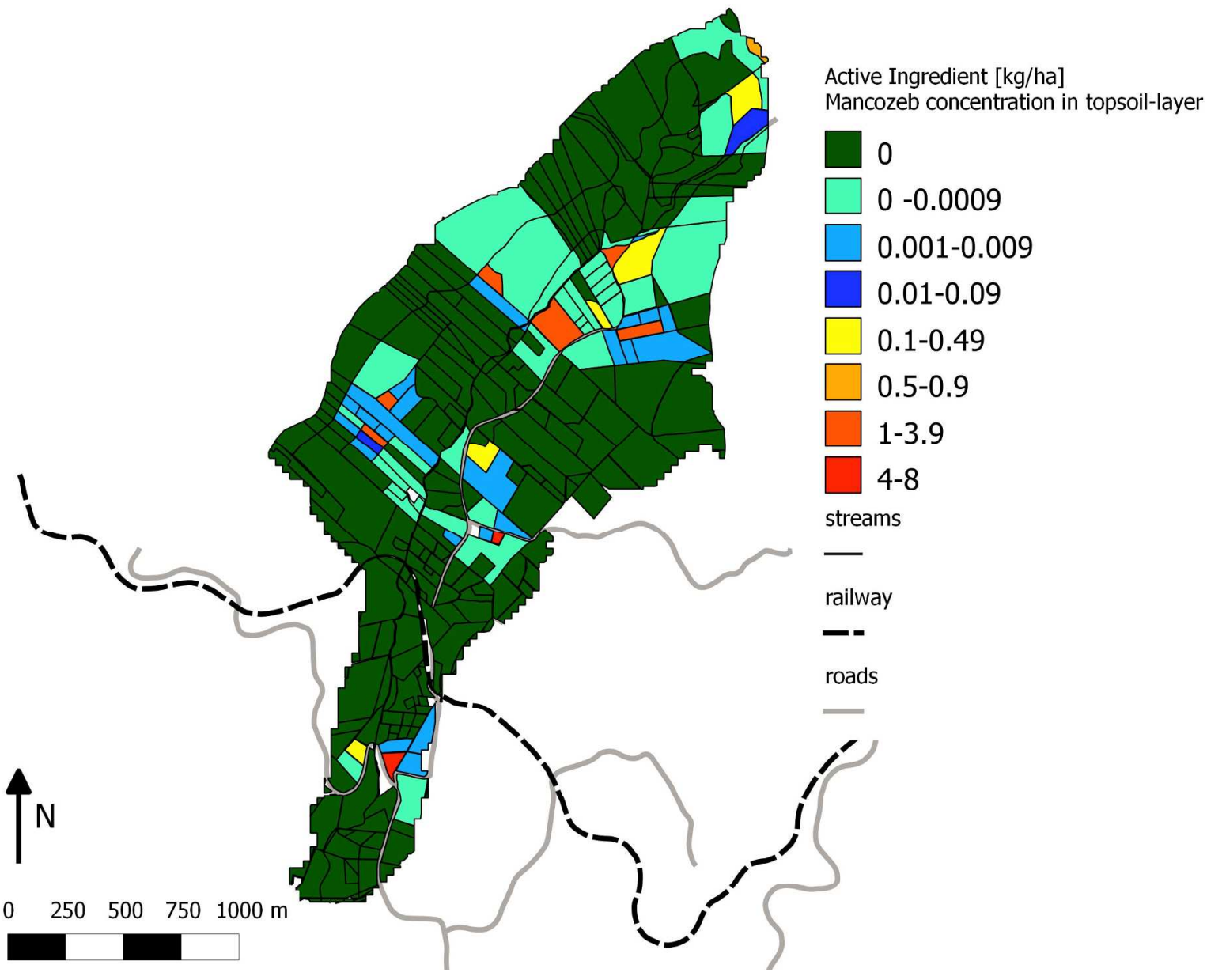

682

683

684

685

686

687

688

689

690 
691 Figure 6:

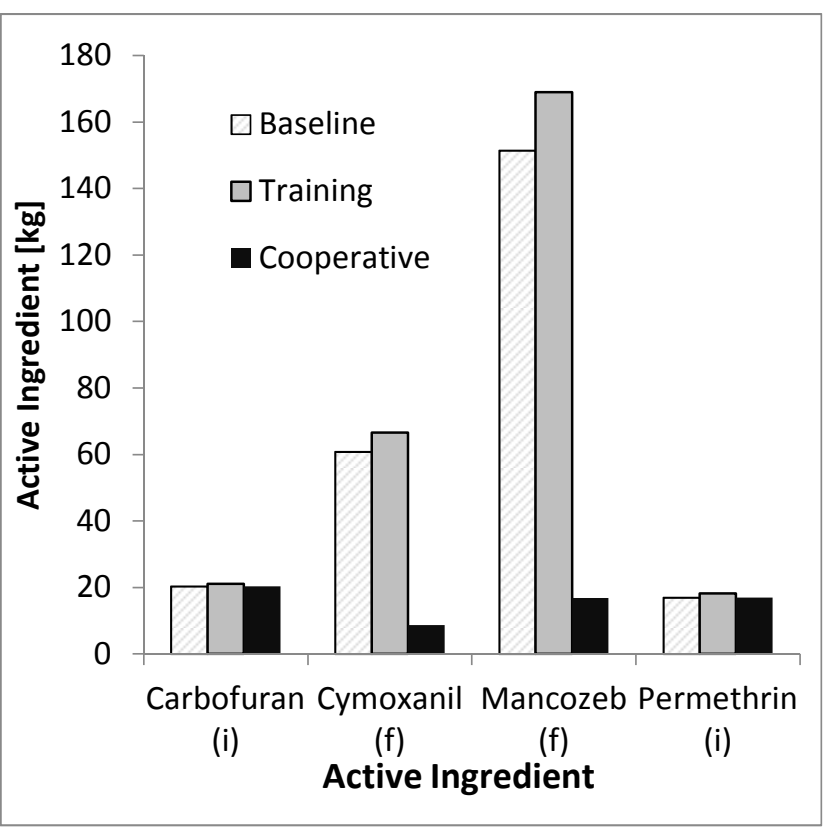

693

694

695

696

697

698

699

700

701

702

703

704

705

706 
$707 \quad$ Figure 7:

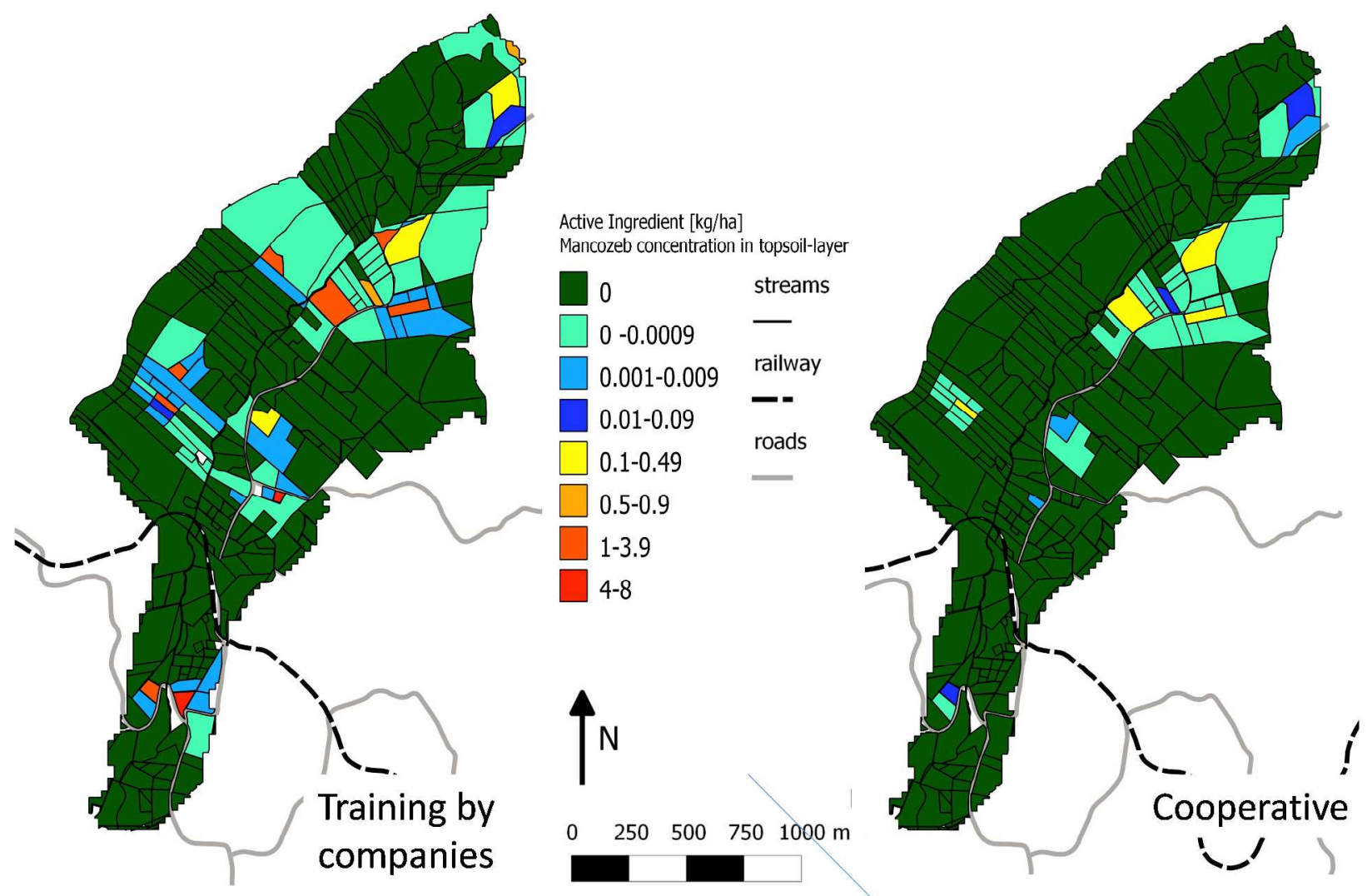


719 TOC graphic
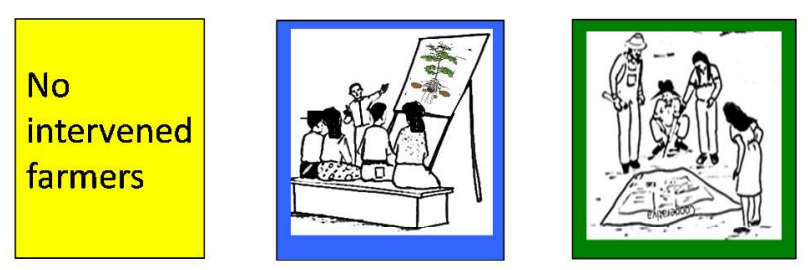

Training by

Cooperative

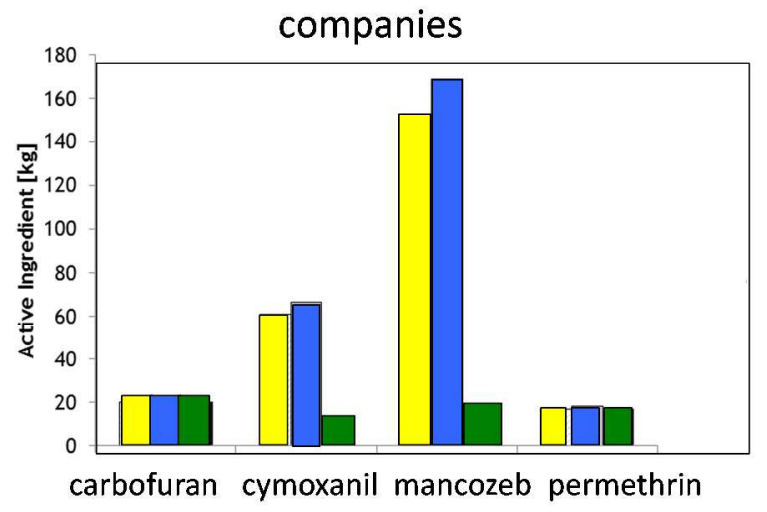

